\title{
Species diversity and population dynamics of fruit flies in bitter gourd ecosystem
}

\author{
Mahesh Math*, Y. K. Kotikal ${ }^{1}$ and Venkateshalu ${ }^{1}$
}

Agricultural and Horticultural Research Station, Kapikad, Ullal, Mangaluru (Karnataka) India ${ }^{1}$ Department of Entomology, College of Horticulture, University of Horticultural Sciences, Bagalkot (Karnataka) India

\section{ARITCLE INFO}

Received : 13.01 .2019

Revised : 25.02 .2019

Accepted : 07.03.2019

\section{KEY WORDS :}

Bitter gourd, Species diversity, Population dynamics, Bactrocera cucurbitae, Bactrocera spp.

*Corresponding author: Email : maheshento@gmail.com

\begin{abstract}
Studies related to species diversity and seasonal incidence of fruit flies in drumstick ecosystems were conducted at University of Horticultural Sciences (UHS), Udyanagiri, Bagalkot, India during Rabi 2015-16 and Kharif 2016. During Rabi 2015 Shannon Wiener index $\left(\mathrm{H}^{\prime}\right)$ of diversity of the fruit fly population was maximum $\left(\mathrm{H}^{\prime}=0.64\right)$ during $6^{\text {th }}$ SMW of (February) 2016. The Pielou's evenness (J') value was maximum during $6^{\text {th }}$ SMW of (February) 2016 and 52 ${ }^{\text {nd }}$ SMW of (December) 2015 (0.92 and 0.79, respectively). The maximum Simpson diversity index value (0.66) was recorded during $6^{\text {th }}$ SMW of (February) 2016. During 2016 maximum $H$ value $\left(H^{\prime}=0.61\right)$ was recorded during $38^{\text {th }}$ followed by $36^{\text {th }}$ SMW of (September) 2016 (0.79). The Pielou's evenness (J') ranged from 0.33 to 0.88 . Maximum (J') value was recorded during $38^{\text {th }} \mathrm{SMW}$ of (September) $2016(0.88)$ and $36^{\text {th }}$ SMW of (September) 2016 (0.79).
\end{abstract}

How to view point the article : Math, Mahesh, Kotikal, Y.K. and Venkateshalu (2019). Species diversity and population dynamics of fruit flies in bitter gourd ecosystem. Internat. J. Plant Protec., 12(1) : 21-27, DOI : 10.15740/HAS/IJPP/12.1/21-27, Copyright@ 2019: Hind Agri-Horticultural Society. 